\title{
ANALISIS POLA ADAPTASI MASYARAKAT TERHADAP KETERBATASAN SUMBERDAYA AIR DI PESISIR KABUPATEN DEMAK
}

\author{
Muh Aris Marfai ${ }^{1)}$, Ahmad Cahyadi'), Guruh Krisnantara ${ }^{3)}$ dan Gin Gin Gustiar ${ }^{4}$ \\ 1,2,3,4 Jurusan Geografi Lingkungan, Fakultas Geografi, Universitas Gadjah Mada \\ Email: arismarfai@yahoo.com, ahmadcahyadi@geo.ugm.ac.id
}

\begin{abstract}
ABSTRAK
Air merupakan kebutuhan pokok bagi kehidupan manusia. Namun demikian, sebaran spasial dan temporal dari sumberdaya air di permukaan Bumi sangat beragam. Pesisir di Kabupaten Demak merupakan salah satu wilayah dengan keterdapatan sumberdaya air yang terbatas disebabkan kondisi geografisnya yang banyak terpengaruh oleh banjir rob. Hal tersebut menyebabkan air permukaan di wilayah tersebut memiliki salinitas yang tinggi. Penelitian ini bertujuan untuk menganalisis pola adaptasi masyarakat terhadap keterbatasan sumberdaya air di pesisir Kabupaten Demak. Kajian dilakukan di Desa Bedono dan Morodemak, Kecamatan Sayung, Kabupaten Demak, Jawa Tengah. Pengumpulan data dilakukan dengan wawancara mendalam dengan beberapa lapisan masyarakat seperti petani, nelayan, tokoh masyarakat dan pegawai pemerintah. Hasil kajian menunjukkan bahwa masyarakat di lokasi kajian memiliki pola adaptasi terhadap keterbatasan sumberdaya air berupa pemanfaatan airtanah dalam di bawah Formasi Breksi Ungaran dengan kedalaman sekitar 80 meter di bawah permukaan tanah. Pengambilan dilakukan oleh beberapa orang anggota masyarakat dan didistribusi dengan mekanisme instalasi air bersih swadaya.
\end{abstract}

Kata Kunci: Adaptasi, Keterbatasan Sumberdaya Air, Pesisir Kabupaten Demak

\section{A. PENDAHULUAN}

Sejak menjadi topik bahasan dalam konferensi tingkat tinggi di Rio de Jenairo, Brazil tahun 1992, perubahan iklim menjadi topik yang mendapat perhatian yang khusus (Forner dan Santoso (2006). Laporan Inter-govermental Panel on Climate Changes (IPCC) tahun 2001, 2002 dan 2007 menunjukkan bahwa perubahan iklim telah banyak berdampak terhadap kehidupan manusia. Kondisi serupa juga diperkirakan akan terjadi di Indonesia (Forner dan Santoso, 2006 dan Susandi, 2006).

Salah satu dampak yang nyata dari perubahan iklim adalah kenaikan muka air laut (Marfai, 2003). Dampak yang ditimbulkan banjir rob bermacam-macam, di antaranya adalah kerusakan infrastruktur, terhentinya aktifitas ekonomi, transportasi, kerusakan lahan perikanan tambak, lahan pertanian dan bahkan kerusakan sumberdaya air (Marfai dkk., 2009 dan Ward dkk., 2010). Kerusakan sumberdaya air dapat berupa semakin tingginya salinitas air permukaan ataupun airtanah, sehingga air tidak dapat digunakan kembali sebagai bahan baku air bersih, khususnya air minum.

Penelitian ini bertujuan untuk melakukan kajian terkait pola adaptasi masyarakat dalam di pesisir Kabupaten Demak yang meliputi Desa Bedono dan desa Morodemak. Penelitian ini diharapkan mampu menggali pola adaptasi yang dilakukan masyarakat, sehingga dapat 
digunakan sebagai bahan pembelajaran serta masukan dalam perencanaan pemenuhan kebutuhan air bersih di wilayah pesisir terdampak banjir rob, khususnya di Indonesia. Kelompok masyarakat menjadi objek kajian dalam penelitian ini mengingat masyarakat adalah kelompok yang akan merasakan secara langsung dampak dari suatu bencana (Wacano dkk., 2013). Selain itu, respon dari suatu masyarakat terhadap bencana akan mencerminkan kemampuan suatu masyarakat dalam memanfaatkan sebaik mungkin sumberdaya yang dimiliki suatu wilayah yang dapat dimanfaatkan untuk menghadapi bencana serta menggambarkan ketangguhan suatu masyarakat dalam mengahadapi bencana (Marfai dkk., 2015). Hal tersebut yang kemudian menyebabkan pentingnya dilakukan kajian tentang respon masyarakat dalam menghadapi bencana.

\section{B. METODE PENELITIAN}

\section{Data Primer}

Data primer diperoleh dengan melakukan survei dan observasi lapangan pada daerah penelitian. Adapun data primer yang menjadi dasar kajian adalah:

a. Hasil observasi lapangan dengan maksud untuk mengidentifikasi dan mengetahui kondisi wilayah secara langsung melalui teknik perekaman deskriptif yaitu hasil pengamatan dan medeskripsikan tampilan fisik.

b. Data hasil indepth interview (wawancara mendalam) dengan beberapa tokoh kunci seperti perangkat desa, pemilik sumur artesis dan masyarakat terpilih di lokasi kajian.

\section{Data Sekunder}

Data sekunder diperoleh melalui inventarisasi dokumen dari institusi-institusi yang terkait yaitu BAPPEDA Kabupaten Demak. Data sekunder yang digunakan terdiri dari:

a. Dokumen RTRW Kabupaten Demak tahun 2011-2016 (Rencana Tata Ruang dan Wilayah), terkait dengan kebijakan pemanfaatan sumberdaya air dan arahan kebijakannya.

b. Dokumen Renstra Wilayah Pesisir Kabupaten Demak 2011-2016.

\section{Analisis Data}

Analisis data yang dilakukan adalah analisis deskriptif kualitatif. Analisis deskriptif kualitatif bertujuan untuk mempertajam hasil observasi lapangan dengan bantuan hasil dari indepth interview ataupun studi literatur.

\section{HASIL PENELITIAN DAN PEMBAHASAN}

1. Analisis Strategi Adaptasi Masyarakat Terhadap Keterbatasan Sumberdaya Air di Desa Bedono, Kecamatan Sayung 
Analisis strategi adaptasi menghadapi kelangkaan air bersih di Desa Bedono, Kecamatan

Sayung dimaksudkan untuk mengetahui sejauh mana masyarakat mampu beradaptasi dengan kondisi lingkungan tempat tinggal mereka terhadap dampak dari banjir rob. Analisis strategi adaptasi akan dikaji melalui sudut pandang coping capacity secara internal yang telah dikembangkan oleh masyarakat setempat. Strategi adaptasi dengan kapasitas internal ditekankan pada analisis deskritif dari pengembangan inovasi dan sistem sosial pengelolaan air bersih yang telah berlangsung bertahun-tahun di Desa Bedono.

\section{a. Adaptasi Masyarakat Melalui Pengembangan Inovasi}

Hasil kajian menunjukan bahwa masyarakat pesisir Desa Bedono telah memiliki strategi adaptasi dalam menghadapi keterbatasan sumberdaya air bersih dengan melakukan pengembangan-pengembangan inovasi yang dilakukan secara bertahap, disesuaikan dengan kondisi fisik air. Salah satu pengembangan inovasi sebagai strategi adaptasi yang dilakukan oleh masyarakat adalah pemanfaatan sumur tanah dalam atau dikenal dengan istilah sumur artesis dengan kedalaman lebih dari 100 meter yang diupayakan menggunakan pompa bermesin sibel yaitu pompa air yang memiliki kemampuan memompa air dari sumber dengan kedalaman lebih dari 80 meter (Gambar 1). Sumur artesis di Desa Bedono hanya berjumlah 1 (satu), yang kepemilikannya oleh seseorang warga, namun sudah dapat melayani sekitar lebih dari 60 rumah tangga. Berikut cuplikan hasil indepth interview kepada pemilik sumur artesis di Desa Bedono yang menggambarkan terdapat pengembangan inovasi terkait pemanfaatan sumur artesis sebagai strategi adaptasi masyarakat.

"Sebelum tahun 2007 sumur artesis yang saya miliki dapat terangkat airnya walaupun hanya dengan menggunakan pompa air sanyo saat kedalamannya hanya 30 meter, kemudian didalamkan lagi hingga 70 meter dan air dipompa dengan jet-pump*, namun semenjak tahun

2007 kondisi air sumur menjadi asin dan berbau sehingga perlu pendalaman sumur lagi hingga 122 meter untuk mendapatkan air yang layak. Untuk mengangkat air dari kedalaman sumur tersebut, hingga saat kami menggunakan pompa air sibel**. Alhamdulillah, hingga saat ini sudah lebih dari 60 rumah yang terlayani." (indepth interview, 2012) (Keterangan: Jet pump dapat menarik air dengan kedalaman hingga 80-100 meter, tergantung model dan power (http://www.flotecpump.com); dan Electric submersible pump (ESP): Pompa submersible mendorong cairan ke permukaan, berbeda dengan jet-pump harus menarik cairan. Submersibles lebih efisien dibandingkan jet-pump. Dapat memompa air dengan

kedalaman ratusan meter (http://www.flotecpump.com)).

"Air dari sumur H. Mahmudi*** dialirkan melalui pipa-pipa. Pemasangan pipa-pipa dan meteran air ini sudah lebih dari 7 tahun, semenjak air sumur dan sungai di sini sudah tidak bisa dipakai untuk keperluan sehari-hari karena asin dan kena banjir rob. Biaya pemasangan pipa dan meteran air berkisar antara Rp. 200.000-Rp. 300.000 tergantung jarak rumah dari sumber air." (indepth interview, 2012) 

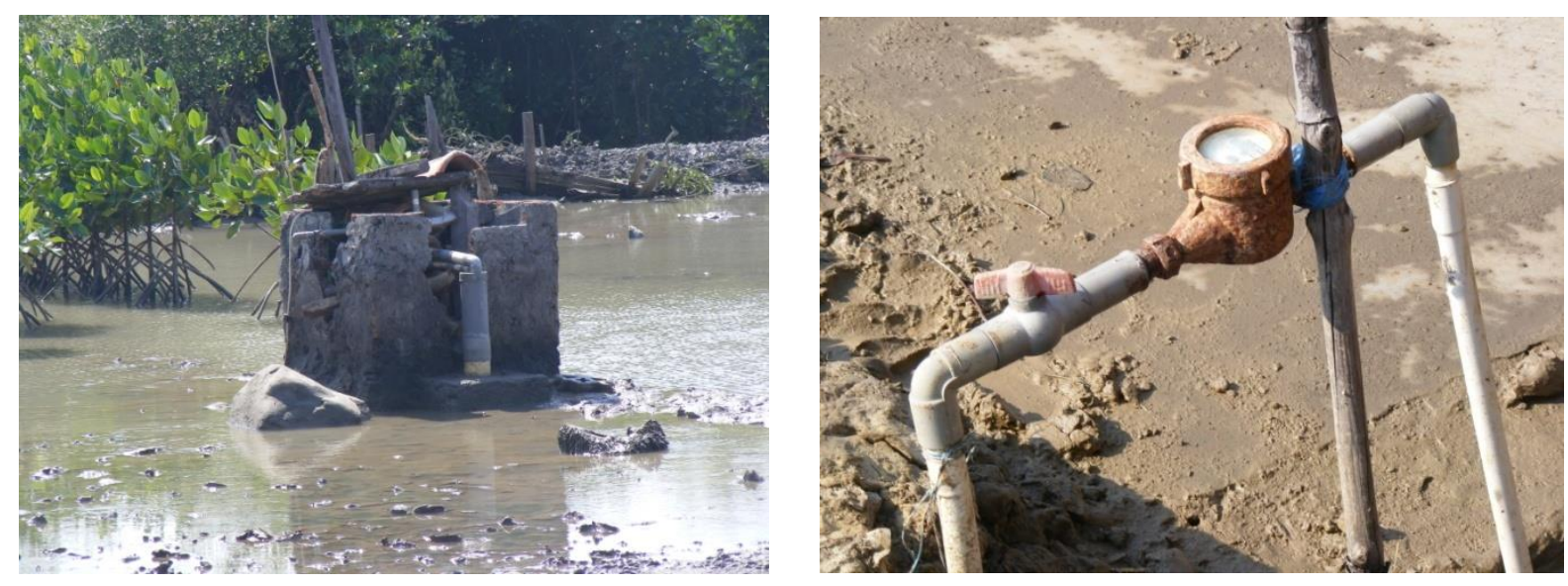

Gambar 1. Sumur Artesis dan Sistem Perpipaan dan Meteran Air

\section{b. Adaptasi Masyarakat Melalui Sistem Sosial Pengelolaan dan Pendistribusian Sumberdaya Air di Desa Bedono}

Berdasarkan hasil observasi lapangan, diketahui bahwa tata kelola sumber air bersih di Desa Bedono sudah sangat terorganisir dan masyarakat telah menerima sistem sosial dan aturan-aturan yang berlaku di dalamnya. Sumur artesis biasanya dimiliki oleh kalangan masyarakat yang dianggap terpandang atau mampu dalam hal financial. Motivasi pemilik sumur artesis untuk mendistribusikan air adalah sosial, sebagai bentuk solidaritas dalam menghadapi bencana yang dihadapi masyarakat pesisir Desa Bedono.

Dalam prakteknya, pengelolaan sumberdaya air di Desa Bedono dilakukan oleh pihak pemilik sumur artesis, tanpa bantuan dari pihak pemerintah ataupun LSM. Pelaksanaannya dilakukan petugas dari pihak pemilik sumur, terutama dalam hal penarikan pembayaran air yang dilakukan setiap minggu. Besar biaya pemanfaatan air disesuaikan dengan jumlah pemakaian yang didasarkan dari perhitungan meteran air tiap rumah. Adapun biaya langganan air yang ditetapkan oleh pemilik sumur artesis adalah $\mathrm{Rp} 2.500 / \mathrm{m}^{3}$. Berdasarkan hasil indepth interview kepada masyarakat (Gambar 2) sejauh ini mereka masih relatif mampu memenuhi tanggung jawabnya dalam hal pembayaran rutin tersebut karena masyarakat sudah sangat terbantu dan air dari sumur artesis ini merupakan satu-satunya sumber air di Desa Bedono khususnya dalam hal memenuhi kebutuhan air untuk keperluan domestik.

"Biasanya Saya membayar air sebesar Rp. 10.000 per-minggu (kurang lebih antara Rp. 40.000-Rp. 60.000 per-bulan, tergantung pemakaian). Ada petugas khusus yang datang langsung menarik pembayaran ke rumah. Bagi Saya, biaya air tidak terlalu berat karena bisa dimanfaatkan untuk macam-macam, seperti mandi, mencuci, minum dan masak. Selain itu juga kami sangat terbantu karena tidak ada pilihan sumber air lainnya." (indepth interview, 

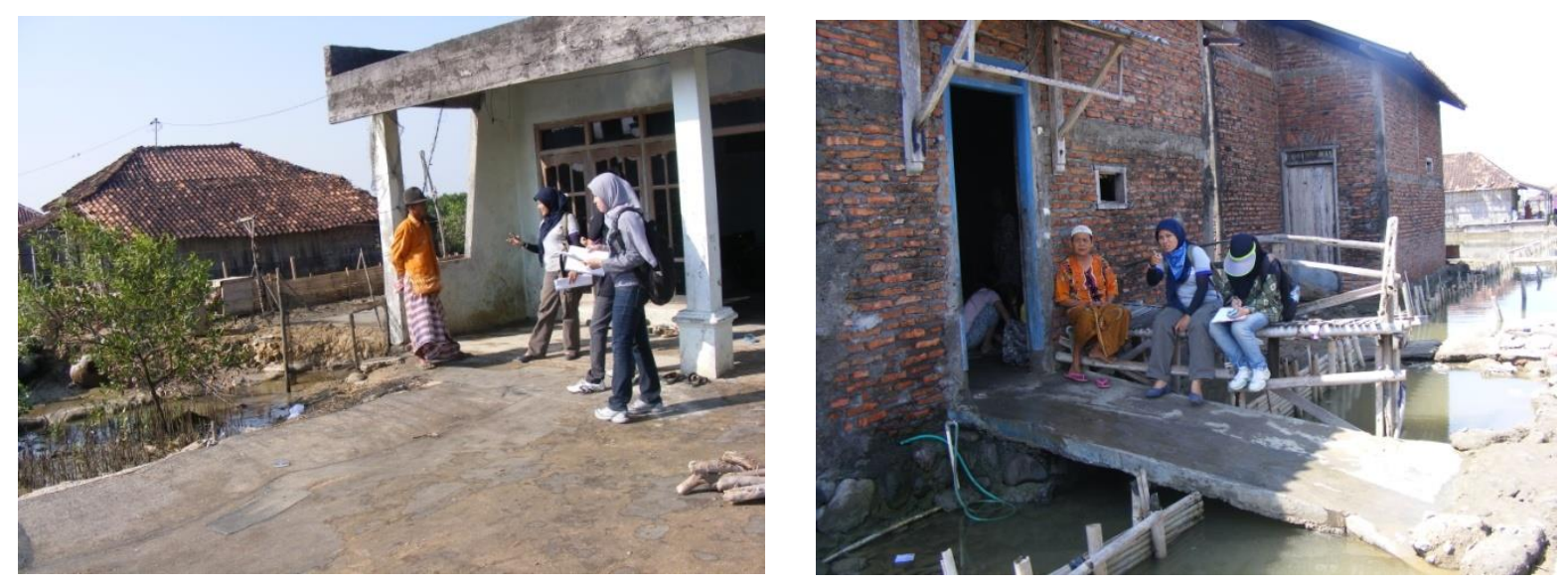

Gambar 2. Kegiatan Indepth Interview dengan Perangkat Desa dan Warga Desa Bedono

\section{c. Implikasi Kebijakan Terkait Arahan Strategi Adaptasi Masyarakat Terhadap Keterbatasan Sumberdaya air di Desa Bedono, Kecamatan Sayung}

Salah satu tujuan yang diharapkan dari penelitian ini adalah memberikan arahan strategi adaptasi menghadapi keterbatasan sumberdaya air di Desa Bedono, Kecamatan Sayung. Kajian ini dilakukan analisis hasil dari strategi adaptasi dengan pendekatan coping capacity internal yang pertimbangannya berpedoman pada pendekatan coping capacity eksternal yaitu terkait dengan kebijakan pemerintah lokal dan nasional mengenai pengelolaan dan pemanfaatan sumberdaya air.

Berdasarkan hasil observasi lapangan terkait dengan kondisi tingkat keparahan rob dan juga intrusi air laut, maka perlu ada upaya-upaya inisiatif baik dari pemerintah, swasta, LSM dan masyarakat untuk mengurangi dampaknya pada sumberdaya air di wilayah kajian. Adapun implikasi kebijakan bagi arahan untuk strategi adaptasi masyarakat terhadap keterbatasan sumberdaya air di Desa Bedono yang dirumuskan dari kajian ini adalah:

1) Eksplorasi/pengeboran dan pemanfaatan air tanah dalam atau yang dikenal dengan sumur artesis di Desa Bedono perlu mempertimbangkan aspek-aspek kelestarian lingkungan, dimana harus ada pembatasan dan kontrol pemerintah lokal terkait pemberian izin usaha-usaha penambahan kedalaman sumur atau jumlah unit sumur di wilayah kajian.

2) Mengurangi porsi pemanfaatan air bersih yang bersumber dari sumur artesis dengan memanfaatkan air bersih hasil pengelolaan air payau. Dalam hal ini, peran pemerintah, swasta, LSM, lembaga pendidikan dan masyarakat sangat penting dalam upaya pengembangan inovasi teknologi tepat guna sebagai solusi keterbatasan air dan pengelolaan air yang berkelanjutan.

3) Penguatan kapasitas kelembagaan sosial yang berkembang di Dususn Bedono dengan cara melakukan kemitraan dengan pihak pemerintah, swasta, LSM atau 
lembaga pendidikan dalam memperluas wilayah pelayanan dan peningkatan kualitas pelayanan air minum/jaringan pipa air minum yang ada secara bertahap melalui peningkatkan manajemen operasi dan pemeliharaan pelayanan air minum.

4) Fokus pada strategi-strategi memperlambat tingkat perkembangan banjir rob dan intrusi air laut dengan cara yaitu sesuai dengan Perpu Bupati Demak No. 11 Tahun 2012: Renstra Wilayah Pesisir Kabupaten Demak 2011-2016. Beberapa strategi yang dimaksud adalah:

a) Memperketat pengawasan Penebangan mangrove untuk pemukiman dan pertambakan;

b) Memperketan perijinan penggalian air tanah dalam;

c) Mengurangi usaha-usaha reklamasi pantai untuk kepentingan industri dan perumahan yang tidak terkontrol;

d) Mengadakan pengkajian tentang alih fungsi lahan;

e) Merancang ulang sistem kanal untuk mengatur keperluan sawah dan tambak;

f) Membangun bendungan (bendung karet) yang mencegah air laut masuk ke badan sungai;

g) Membangun bangunan pantai dan bangunan air yang sesuai untuk mencegah air laut masuk kawasan pemukiman dan persawahan; dan

h) Mensosialisasikan pengelolaan yang baik untuk pengembangan pertanian, kehutanan,

i) perikanan, pembuatan jalan umum dan pembangunan pemukiman yang berwawasan lingkungan.

\section{Adaptasi Masyarakat Pesisir Terhadap Keterbatasan Sumberdaya Air di Morodemak}

Daerah pesisir Morodemak secara administratif berada di Kecamatan Bonang dengan luasan $8324 \mathrm{Ha}$ atau 9,28 \% dari luas keseluruhan Kabupaten Demak (Demak dalam Angka, 2011). Secara geografis Pesisir Morodemak memiliki relief yang cenderung landai hingga datar dengan elevasi 0-3 meter dpal dan memiliki tekstur tanah halus (liat) dan tanah sedang (lempung) (Demak dalam Angka, 2011).

Adaptasi masyarakat pesisir Morodemak dalam menghadapi keterbatasan sumberdaya air bersih akan dikaji, baik pada sistem air tanah maupun sungai yang dipengaruhi oleh kondisi fisik dan proses dinamika pesisir. Adapun batasan daerah penelitian yang akan dikaji meliputi perkampungan sepanjang sungai yang bermuara ke laut di sekitar PPI (Pelabuhan Perikanan Pantai) Morodemak dengan ciri utama masyarakatnya sebagai nelayan hingga perkampungan di sepanjang sungai ke arah hulu yang memiliki perbedaan pemanfaatan lahan berupa lahan sawah dengan ciri mayoritas masyarakatnya sebagai petani. 


\section{a. Penggunaan Sumur Bor dan PAM}

Penggunaan sumur bor merupakan salah satu bentuk adaptasi masyarakat pesisir PPI dalam merespon kesulitan memperoleh air bersih sebagai upaya pemenuhan kebutuhan domestik seperti minum dan MCK. Namun dibutuhkan biaya tidak sedikit untuk membuat sumur bor. Air tanah dangkal (sumur gali) dengan biaya pembuatan dan perawatan jauh lebih hemat dibanding sumur bor, tidak ditemukan di daerah tersebut. Kondisi tersebut dapat disebabkan oleh kerentanan yang tinggi di perkampungan sekitar PPI terhadap banjir rob oleh pasang air laut khususnya pada waktu bulan jawa ke-2 dan ke-3. Tanah yang kerap tergenang oleh banjir rob menyebabkan tanah mudah jenuh oleh air laut yang dapat meresap pada zona aerasi (zona tidak jenuh air). Pada zona ini belum dapat ditemukan air tawar dan air masih bersifat payau. Kondisi tersebut dapat menjadi salah satu alasan tidak digunakannya air tanah dangkal (aquifer bebas) seperti sumur gali di kawasan ini.

Pembuatan sumur bor yang membutuhkan biaya tidak sedikit hanya dapat diakses oleh warga dengan kondisi ekonomi mampu atau memiliki pendapatan tetap. Pemilik sumur bor menjadikan kondisi ini sebagai peluang bisnis karena bagi warga yang menyalur air pada mereka dikenakan biaya. Sedangkan, warga dengan mata pencaharian utama sebagai nelayan buruh dengan pendapatan tidak tetap, tidak mampu untuk membuat sumur bor sendiri, dan lebih memilih menyalur pada pemilik sumur bor di sekitarnya. Beberapa pemilik sumur bor di perkampungan sekitar Pelabuhan Morodemak yang dapat diwawancarai, mengenakan tarif yang bervariasi kepada warga yang menyalur air bersih. Biaya penyaluran air ditentukan berdasarkan cara yang berbeda-beda pula, baik berdasarkan banyaknya penggunaan air ataupun banyaknya air yang dipompa dalam waktu tertentu.

Salah seorang pemilik sumur bor dengan kedalaman sumur sekitar 85 meter, sejak tahun 1985 hingga saat ini telah memberikan jasa penyaluran air kepada 40 kepala keluarga. Adapun biaya yang dikenakan pada awal pemasangan pipa Rp. 200 ribu dengan biaya selanjutnya Rp. $2500,00 / \mathrm{m}^{3}$ per satu minggu. Hasil wawancara dengan salah seorang warga, dengan keluarga terdiri dari suami-istri dengan tiga anak, yang menyalur jasa air bersih pada pemilik sumur bor tersebut, dalam waktu seminggu dikenakan biaya Rp. 7.500,00 10.000,00 untuk keperluan minum dan MCK sehari-hari. Dengan demikian konsumsi air bersih untuk kebutuhan domestik dalam satu minggu sekitar $3-4 \mathrm{~m}^{3}$ atau sekitar 85,7 - 114 liter /hari/ orang. Pemilik sumur bor lainnya sejak tahun 1993 hingga saat ini telah mampu melayani 70 kepala keluarga. Pemilik tersebut mengenakan biaya penggunaan air berdasarkan lamanya pemompaan. Sumur dengan kedalaman 80 meter tersebut mampu memompa air 50 liter/menit $\left(0,05 \mathrm{~m}^{3} /\right.$ menit). Pemompaan air selama satu jam dikenakan biaya Rp.3000,00 atau dalam satu jam air yang dapat dipompa sebanyak $3 \mathrm{~m}^{3}$. Dengan demikian biaya yang dikenakan Rp. 1000,00/ $\mathrm{m}^{3}$. Kondisi air tanah sumur bor di 
perkampungan sekitar Pelabuhan Morodemak memiliki kualitas baik terutama untuk kelayakan kebutuhan air minum.

Alternatif lain, adaptasi terhadap keterbatasan air bersih di perkampungan Pelabuhan Morodemak adalah dengan menggunakan sumber air PAM yang dikelola oleh pemerintah. Namun, kondisi ini menimbulkan konflik terhadap pemanfaatan sumur bor dan PAM. Biaya instalasi yang mahal dan kondisi air yang kurang jernih dibanding air sumur bor, menjadi alasan bagi masyarakat untuk tetap memilih menggunakan air sumur bor.

Perkampungan pesisir dengan ciri utama masyarakat petani, yang terletak sekitar 3 kilometer dari muara di Pelabuhan Morodemak, umumnya menggunakan sumber air bersih dari jasa PAM untuk pemenuhan MCK. Adapun kebutuhan minum diatasi dengan pembelian air mineral galon. Sedangkan, penggunaan sumur bor ataupun sumur gali tidak ditemukan di perkampungan ini.

\section{b. Adaptasi Terhadap Intrusi Air Laut ke Hulu Sungai}

Perkampungan masyarakat petani pesisir yang terletak di Desa Gedang, Kecamatan Bonang yang berjarak sekitar tiga kilometer dari muara sungai Pelabuhan Morodemak memiliki fenomena pemanfaatan lahan utama berupa lahan sawah padi cukup luas (Gambar 3). Lahan tambak yang luas sudah tidak ditemukan di perkampungan ini. Namun pengaruh proses laut seperti intrusi air laut masih dapat diidentifikasi pada sungai yang bermuara ke laut Pelabuhan Morodemak. Air sungai yang masih bersifat payau sebagai salah satu indikator adanya pengaruh intrusi air laut. Kondisi ini merupakan masalah bagi masyarakat pesisir dengan sumber mata pencaharian berasal dari lahan pertanian. Air sungai tersebut merupakan sumber irigasi bagi lahan sawah yang cukup luas di daerah tersebut. Perilaku intrusi air laut yang bersifat dinamis akan mengganggu pertumbuhan tanaman padi yang membutuhkan pengairan air sungai yang tawar atau tidak mengandung air laut. Selanjutnya kondisi ini akan menurunkan produktivitas padi bagi para petani dan menurunkan sumber pendapatan ekonomi mereka. 


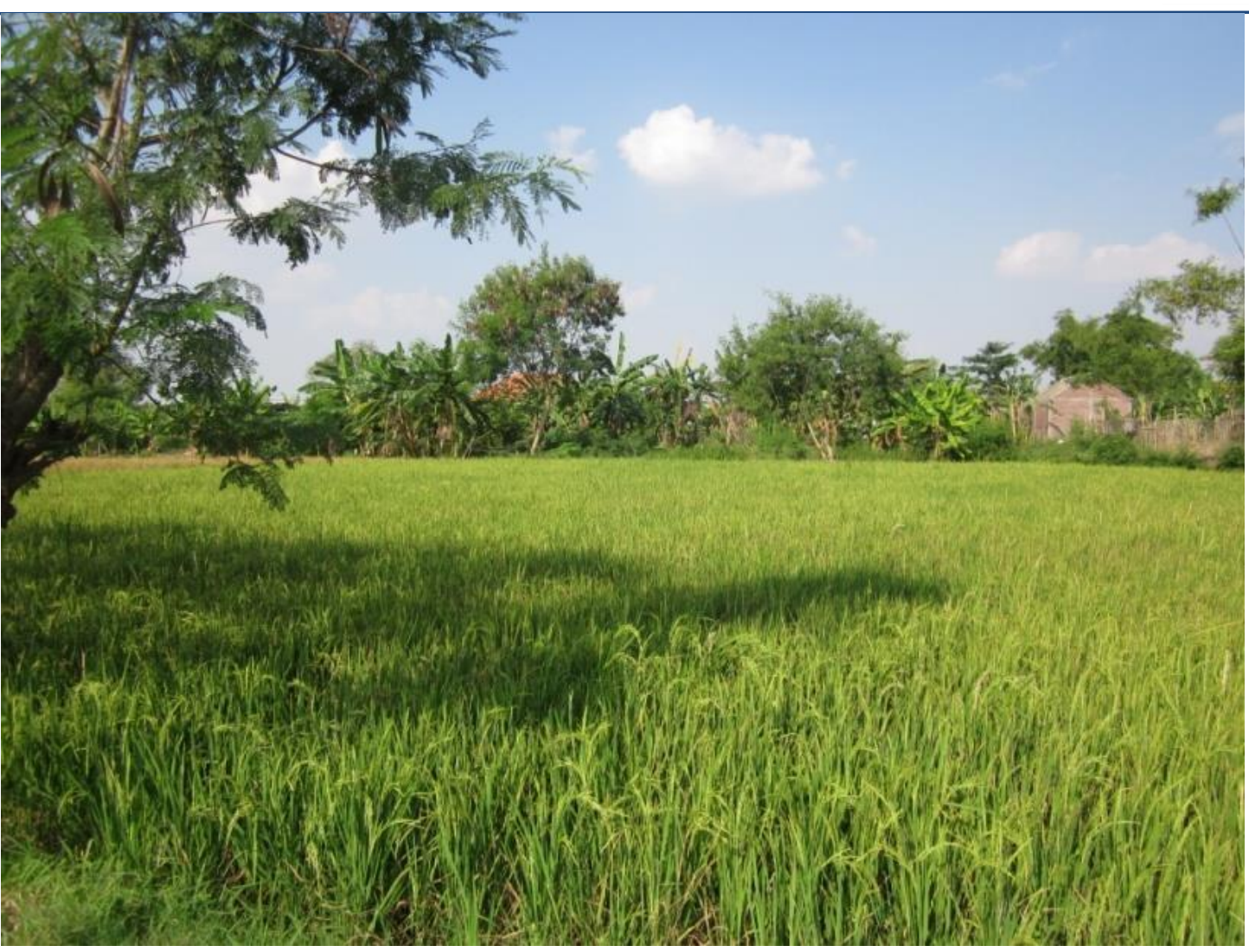

Gambar 3. Persawahan di Morodemak

Adaptasi para petani dalam merespon keterbatasan air sungai yang tercampur oleh intrusi air laut yaitu dengan mengetahui masa-masa ketika terjadi pasang air laut tinggi. Para petani menyesuaikan kondisi tersebut terhadap masa tanam padi mereka. Sehingga saat terjadi intrusi dan air sungai tidak layak digunakan untuk irigasi, tanaman padi sudah berumur tua. Masa panen padi di daerah ini terjadi sebanyak dua kali dalam setahun dan saat terjadi intrusi air laut, lahan sawah dibiarkan tidak ditanami (bero).

Tingginya kegiatan pertanian sawah padi di perkampungan pesisir ini menyebabkan masalah pada sistem sungai berupa fenomena eutrofikasi atau pertumbuhan enceng gondok yang tidak terkendali akibat dari limbah pupuk yang tinggi. Selanjutnya, limbah pupuk dan enceng gondok tersebut dapat mencemari air sungai menjadi lebih keruh dan menganggu sistem biota sungai. Sehingga menghalangi sinar matahari yang masuk yang penting bagi sistem biota sungai. Kondisi tersebut selanjutnya diperparah dengan fenomena intrusi air laut yang mendesak kearah hulu sungai yang dapat berdampak pada penurunan biodiversity sistem biota sungai. Karena biota sungai yang berair tawar memiliki sistem yang berbeda dengan biota sungai yang berada di dekat muara yang lebih tahan dengan kondisi air yang payau. Jika kondisi alami sistem sungai berubah akan menyebabkan kepunahan biota alami awal.

Penggunaan sumur bor yang semakin meningkat sebagai bentuk adaptasi masyarakat pesisir dalam mengatasi keterbatasan air bersih untuk memenuhi kebutuhan domestik, dalam 
kurun waktu lama akan menyebabkan permasalahan lingkungan baru seperti land subsidence, genangan banjir rob semakin meluas, intrusi air laut pada sistem air tanah, ketidakstabilan pada infrastruktur di kawasan pesisir, dan dampak lainnya. Perlu adanya upaya atau strategi adaptasi yang arif dan berkelanjutan yang ramah lingkungan yang melibatkan seluruh pihak yang berpengaruh termasuk masyarakat pesisir sendiri, pemerintah daerah dan aparat desa. Upaya nyata yang dapat dilakukan adalah pemerintah daerah perlu membuat kebijakan pembatasan pembuatan sumur bor dengan adanya pengawasan oleh aparat desa. Hal tersebut dapat dilakukan dilakukan dengan pemanfaatan sumur bor dengan pengelolaan secara bersama dan tidak dipandang sebagai peluang bisnis yang cenderung merusak lingkungan. Perlu adanya sosialisasi mengenai strategi-strategi adaptasi ramah lingkungan yang berdasarkan pada pengelolaan pesisir berkelanjutan kepada para warga masyarakat oleh pemerintah daerah yang didukung dengan aparat desa. Disamping itu, disosialisasikan pula dampak yang akan terjadi dari pembuatan sumur bor yang melebihi daya dukung lingkungan, akan menimbulkan permasalahan lingkungan baru. Sosialisai kepada masyarakat pesisir dengan latar belakang kondisi sosial ekonomi yang kompleks perlu dibuat dengan cara yang lebih mudah dipahami.

Permasalahan intrusi air laut yang mendesak ke arah hulu sungai selain disebabkan oleh faktor alami akibat kenaikan muka air laut dan kondisi musim, juga disebabkan oleh faktor yang berasal dari kegiatan manusia di muara sungai. Faktor lokal seperti land subsidence akibat pembuatan dan pemanfaatan sumur bor yang berlebihan di daerah muara ikut memperparah kenaikan muka air laut ke arah hulu sungai. Dengan demikian perlu adanya strategi adapatasi yang dilakukan secara terintegrasi antara masyarakat pesisir di muara dan di hulu sungai yang masih terpengaruh proses dinamika pesisir. Pengendalian penggunaan pupuk dengan cara yang lebih ramah lingkungan yang dapat dilakukan oleh masyarakat pesisir hulu sungai, akan mengurangi pendangkalan dan pencemaran sungai dan melindungi biota sungai. Sedangkan pada masyarakat pesisir di daerah muara berupaya dalam mengendalikan pembuatan sumur bor seperti yang telah dijelaskan diawal.

\section{KESIMPULAN DAN SARAN}

Strategi adaptasi masyarakat di wilayah pesisir Kabupaten Demak dalam menghadapi keterbatasan sumberdaya air dilakukan melalui pemanfaatan airtanah dalam yang dikelola secara bersama ataupun perorangan dengan sistem PAM Swadaya. Selain itu, adapatasi terhadap salinitas yang tinggi dilakukan dengan melakukan perubahan penggunaan lahan dari sawah menjadi tambak, serta pembendungan sungai di bagian hilir ketika terjadi pasang airlaut atau banjir rob. 


\section{E. DAFTAR PUSTAKA}

Forner, C. dan Santoso, H. 2006. Climate Change Projection for Indoensia, Background Document for The Southeast Asia Kick-off Meeting of The Project Tropical Forest and Climate Change Adaptation. Bogor: CIFOR.

IPCC. 2001. IPCC Third Assessment Report, Climate Change 2001: The Sciencetific Basis. IPCC Working Group III.

IPCC. 2002. IPCC Special Report Emission Scenario. IPCC Working Group III.

IPCC. 2007. IPCC Fourt Assessment Report: The Physical Science Basis. IPCC Working Group I.

Marfai, M.A. 2003. GIS Modeling of River and Tidal Flood Hazards in Water Front City: Case Study Semarang City, Central Java, Indonesia. MSc Thesis. Enschede, The Netherland: ITC.

Marfai, M.A.; Yulianto, F.; Hizbarin, D.R.; Ward, P. dan Aerts, J.C.J.H.. 2009. Preliminary Assessment and Modelling the effects of Climate Change on Potential Coastal Flood Damage in Jakarta. Joint Research Resport. Vree Univerisity, Amsterdam dan Fakultas Geografi Universitas Gadjah Mada Yogyakarta.

Marfai, M.A.; Rahayu, E. dan Triyanti, A. 2015. Peran kearifan Lokal dan Modal Sosial dalam Pengurangan Risiko Bencana dan Pembangunan Pesisir: Integrasi Kajian Lingkungan, Kebencanaan dan Sosial Budaya. Yogyakarta: Gadjah Mada University Press.

Susandi, A. 2006. The Impact of International Green House Gas Emition Reduction on Indonesia: Report on System Science. Hamburg, Germany: Max Planck Institute for Meteorology.

Wacano, D.; Rif’an, A.A.; Yuniastuti, E.; Daulay, R.W. dan Marfai, M.A. Adaptasi Masyarakat Pesisir Kabupaten Demak dalam Menghadapi Perubahan Iklim dan Bencana Wilayah Kepesisiran. dalam Marfai, M.A. dan Widyastuti, M. 2013. Pengelolaan Lingkungan Zamrud Khatulistiwa. Yogyakarta: Buku Pintal.

Ward, P.J.; Marfai, M.A.; Fajar, Y.; Hizbaron, D.R.; dan Aert, J.C.J.H. 2010. Coastal Inundation Damage Exposure Estimation: A Case Study for Jakarta. Natural Hazard. Springer.

\section{F. UCAPAN TERIMA KASIH}

Penelitian ini merupakan hibah dosen Fakultas Geografi Universitas Gadjah Mada Tahun 2015. Penulis mengucapkan terimakasih yang sebesar-besarnya atas ijin penelitian, biaya dan segala dukungan yang diberikan oleh Fakutas Geografi, sehingga pelaksanaan penelitian ini dapat selesai sesuai dengan rencana. 